\title{
Growth performance and element concentrations reveal the calcicole- calcifuge behavior of three Adiantum species
}

\author{
Jian Xiong Liao ${ }^{1,2^{*}}$ D, Dan Yang Liang ${ }^{2}$, Qian Wen Jiang ${ }^{1}$, Ling Mo ${ }^{1}$, Gao Zhong Pu ${ }^{1}$ and Deng Zhang ${ }^{1}$
}

\begin{abstract}
Background: The calcicole or calcifuge behavior of wild plants has been related to element deficiency or toxicity. For fern species, however, knowledge about their adaptive differences and responses to soil environmental changes is virtually absent. In the karst regions of southern China, most Adiantum species favor calcareous soils, but $A$. flabellulatum prefers acidic soils. Such contrasting preferences for soil types in the same genus are interesting and risky because their preferred soils may "pollute" each other due to extreme precipitation events. We mixed calcareous and acidic soils at 1:1 ( $(\mathrm{v} / \mathrm{v})$ to simulate the "polluted" soils and grew three Adiantum species (the calcicole A. capillus-veneris $\mathrm{f}$. dissectum and A. malesianum and the calcifuge $A$. flabellulatum) on the calcareous, acidic and mixed soils for $120 \mathrm{~d}$ and assessed their growth performance and element concentrations.
\end{abstract}

Results: The calcareous soil showed the highest $\mathrm{pH}, \mathrm{Ca}, \mathrm{Mg}$ and $\mathrm{P}$ concentrations but the lowest $\mathrm{K}$ concentration, followed by the mixed soil, and the acidic soil. After $120 \mathrm{~d}$ of growth, the calcifuge A. flabellulatum on the calcareous and mixed soils exhibited lower SPAD and relative growth rate (RGR) than those on the acidic soil, and its leaf and root $\mathrm{Ca}, \mathrm{Mg}$ and Fe concentrations were higher and $\mathrm{K}$ was lower on the calcareous soil than on the acidic soil. The calcicole A. capillus-veneris f. dissectum on the calcareous soil had similar leaf element concentrations and RGR with those on the mixed soil, but their leaf $\mathrm{Ca}$, Fe and Al were lower and leaf $\mathrm{P}$ and $\mathrm{K}$ concentrations, SPAD and RGR were higher than those on the acidic soil. For the calcicole A. malesianum, leaf Ca, Fe and Al were lowest and leaf P and RGR were highest when grown on the mixed soil, intermediated on the calcareous soil, and on the acidic soil. Compared with A. malesianum, A. capillus-veneris f. dissectum had lower leaf $\mathrm{Ca}$, Fe and $\mathrm{Al}$ but higher leaf $\mathrm{Mg}$ concentration when grown on the same calcareous or mixed soils.

\footnotetext{
* Correspondence: liaojianx@163.com

'Guangxi Key Laboratory of Plant Conservation and Restoration Ecology in Karst Terrain, Guangxi Institute of Botany, Guangxi Zhuang Autonomous Region and Chinese Academy of Sciences, Guilin, P.R. China ${ }^{2}$ College of Tourism \& Landscape Architecture (College of Plant and Ecological Engineering), Guilin University of Technology, Guilin, P.R. China
}

(c) The Author(s). 2020 Open Access This article is licensed under a Creative Commons Attribution 4.0 International License, which permits use, sharing, adaptation, distribution and reproduction in any medium or format, as long as you give appropriate credit to the original author(s) and the source, provide a link to the Creative Commons licence, and indicate if changes were made. The images or other third party material in this article are included in the article's Creative Commons licence, unless indicated otherwise in a credit line to the material. If material is not included in the article's Creative Commons licence and your intended use is not permitted by statutory regulation or exceeds the permitted use, you will need to obtain permission directly from the copyright holder. To view a copy of this licence, visit http://creativecommons.org/licenses/by/4.0/ The Creative Commons Public Domain Dedication waiver (http://creativecommons.org/publicdomain/zero/1.0/) applies to the data made available in this article, unless otherwise stated in a credit line to the data. 


\begin{abstract}
(Continued from previous page)
Conclusions: A. capillus-veneris f. dissectum is a low leaf Ca calcicole species while A. malesianum is an Al accumulating calcicole species. They can effectively take up P and $\mathrm{K}$ to leaves and hence can thrive on calcareous soils. In contrast, the calcifuge A. flabellulatum grown on calcareous soils is stunted. Such growth performance may be attributed to the increased leaf $\mathrm{Ca}$ and decreased leaf $\mathrm{K}$ concentration. If their preferred soils are "polluted", A. flabellulatum can grow worse, A. capillus-veneris f. dissectum can remain almost unaffected while A. malesianum will perform better.
\end{abstract}

Keywords: Adiantum species, Acidic soils, Calcareous soils, Calcicole, Calcifuge, Element concentration

\section{Background}

Calcareous and acidic soils are the predominant soil types in the karst regions of southern China [1,2]. They are adjacent but strongly differ in their vegetation $[3,4]$. With the increase of economic activities and extreme rainstorm frequencies, the two contrasting soils may "pollute" each other [5] and hence their specialized wild plants may face survival risk. Therefore, studies on the adaptive differences and mechanisms of these calcicolecalcifuge plants are crucial for understanding their growth and distribution and for predicting their responses to possible soil environmental changes.

Element deficiency or toxicity is thought to relate to calcicole or calcifuge behavior of wild plants. On calcareous soils, calcicole plants can regulate nutrient uptake via root architectural or exudation plasticity [6,7], while calcifuge species are limited by low nutrient availability $[6,8]$ or deleterious precipitation of Ca-phosphate [9] or Caenhanced $\mathrm{P}$ toxicity [10]. In turn, calcicole plants can suffer from toxicity symptoms by excess $\mathrm{Al}^{3+}$ or $\mathrm{Fe}^{2+}$ at acidic sites $[11,12]$. In these existing studies, most calcicole and/ or calcifuge species were seed plants and they were generally grown on calcareous or acidic soils $[9,13]$. For fern species, to the best of our knowledge, the mechanisms causing their calcicole-calcifuge behavior are largely unexplored. Moreover, plants grown on calcareous and acidic mixed soils, to analyze their responses to "polluted" soil conditions, are also virtually absent.

Adiantum species (Pteridaceae) are important medicinal, ornamental ferns and environmental indicators. In the karst regions of southern China, most of them are found on calcareous soils, but A. flabellulatum only grows on acidic soils [14]. Such contrasting preferences for soil types in the same genus are interesting, but are not well understood [15]. In this context, we selected three Adiantum species (the calcicole A. capillus-veneris f. dissectum and A. malesianum, and the calcifuge A. flabellulatum) and grew them on calcareous, acidic and mixed soils. We assessed their biomass, relative growth rate (RGR), chlorophyll (SPAD values) and element concentrations. The objectives were to compare the performance of three Adiantum species on three soil types. We hypothesized that: (i) on calcareous soils, the calcicole $A$. capillus-veneris f. dissectum and A. malesianum would perform better than the calcifuge A. flabellulatum, and that on acidic soils, the opposite would be true; (ii) all three species would perform worse on mixed soils than on their respective optimum soils; (iii) their calcicole or calcifuge behavior might be attributed to element deficiency and/or toxicity.

\section{Results}

\section{Soil properties}

The calcareous soil had higher $\mathrm{pH}, \mathrm{Ca}, \mathrm{Mg}$ and $\mathrm{P}$ concentrations but lower $\mathrm{K}$ concentration when compared with the acidic soil $(P<0.05$, Table 1$)$. After mixing the calcareous and acidic soils at 1:1, the mixed soil had similar $\mathrm{pH}$ with the calcareous soil $(P>0.05)$, but its $\mathrm{Ca}$, $\mathrm{Mg}, \mathrm{P}$ and $\mathrm{K}$ concentrations were intermediate between the calcareous and acidic soils $(P<0.05)$. For $\mathrm{Fe}$ and $\mathrm{Al}$ concentrations, the three soil types did not differ $(P>0.05)$.

\section{Plant growth characteristics}

After $120 \mathrm{~d}$ of growth, A. flabellulatum on the calcareous and mixed soils were stunted and total biomass were lower than those grown on the acidic soil $(P<0.05$, Fig. 1). In contrast, $A$. capillus-veneris f. dissectum and A. malesianum performed worse and total biomass were lower when grown on the acidic soil $(P<0.05)$. When grown on the mixed soil, all three species had similar

Table 1 Chemical analysis of the acidic, calcareous and mixed soils used in this study

\begin{tabular}{llll}
\hline & Acidic soil & Calcareous soil & Mixed soil \\
\hline $\mathrm{pH}(\mathrm{in} \mathrm{CaCl})$ & $4.71 \pm 0.14^{\mathrm{b}}$ & $7.76 \pm 0.04^{\mathrm{a}}$ & $7.50 \pm 0.04^{\mathrm{a}}$ \\
$\mathrm{Ca}\left(\mathrm{mg} \mathrm{g}^{-1}\right)$ & $0.53 \pm 0.03^{\mathrm{c}}$ & $66.35 \pm 1.13^{\mathrm{a}}$ & $30.75 \pm 1.04^{\mathrm{b}}$ \\
$\mathrm{Mg}\left(\mathrm{mg} \mathrm{g}^{-1}\right)$ & $2.83 \pm 0.04^{\mathrm{c}}$ & $32.48 \pm 0.53^{\mathrm{a}}$ & $16.86 \pm 0.57^{\mathrm{b}}$ \\
$\mathrm{Fe}\left(\mathrm{mg} \mathrm{g}^{-1}\right)$ & $43.30 \pm 1.05^{\mathrm{a}}$ & $47.67 \pm 1.26^{\mathrm{a}}$ & $46.58 \pm 1.40^{\mathrm{a}}$ \\
$\mathrm{Al}\left(\mathrm{mg} \mathrm{g}^{-1}\right)$ & $69.71 \pm 1.85^{\mathrm{a}}$ & $76.26 \pm 2.17^{\mathrm{a}}$ & $73.52 \pm 1.27^{\mathrm{a}}$ \\
$\mathrm{P}\left(\mathrm{mg} \mathrm{g}^{-1}\right)$ & $0.37 \pm 0.01^{\mathrm{c}}$ & $1.00 \pm 0.03^{\mathrm{a}}$ & $0.73 \pm 0.02^{\mathrm{b}}$ \\
$\mathrm{K}\left(\mathrm{mg} \mathrm{g}^{-1}\right)$ & $12.68 \pm 0.09^{\mathrm{a}}$ & $2.59 \pm 0.09^{\mathrm{c}}$ & $7.38 \pm 0.25^{\mathrm{b}}$ \\
\hline
\end{tabular}

All the element concentrations are total concentrations. Values are means $\pm \mathrm{SE}$ of 3 replicates from one-way ANOVA. Different letters indicate significant differences among soil types $(P<0.05)$. 


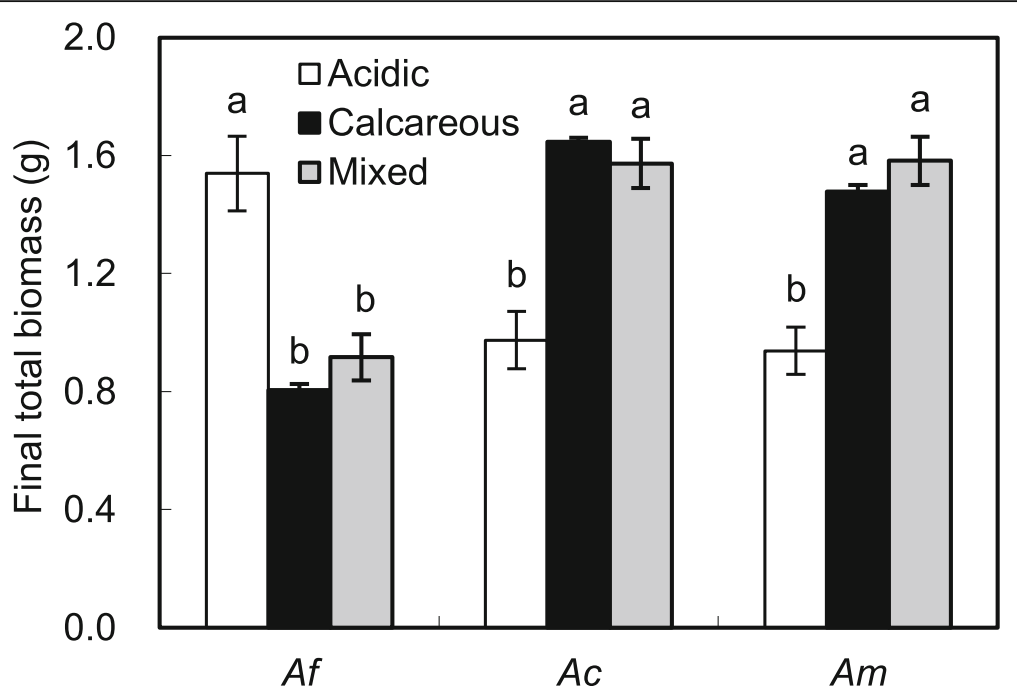

Fig. 1 Final total biomass of the calcifuge Adiantum flabellulatum (Af) and the calcicole A. capillus-veneris f. dissectum (Ac) and A. malesianum (Am) grown on acidic, calcareous and mixed soils. Bar are means \pm SE of 7 replicates from two-way ANCOVA. Different letters indicate significant differences in the same species $(P<0.05)$

total biomass with those grown on the calcareous soil $(P>0.05)$.

When grown on the calcareous and mixed soils, A. flabellulatum exhibited chlorotic and necrotic spots on pinnules and lower chlorophyll contents (SPAD values) than those grown on the acidic soil $(P<0.05$, Fig. 2a). Conversely, A. capillus-veneris f. dissectum and A. malesianum showed chlorotic symptoms and the lowest chlorophyll contents when grown on the acidic soil. For the symptoms, the margins of older pinnules of $A$. capillus-veneris f. dissectum were scorched while A.malesianum exhibited chlorotic stripes on older pinnules and then whole pinna shriveled. RGR of A. flabellulatum was higher when grown on the acidic soil than on the calcareous and mixed soils $(P<0.05$, Fig. $2 b)$. In $A$. capillusveneris $\mathrm{f}$. dissectum and $A$. malesianum, however, the highest and the lowest RGR occurred on the mixed and acidic soils, respectively. Compared with A. flabellulatum,
A. capillus-veneris f. dissectum and A. malesianum had higher chlorophyll contents and RGR when grown on the calcareous or mixed soil $(P<0.05$, Fig. 2$)$. When grown on the acidic soil, chlorophyll contents and RGR of $A$. capillus-veneris $\mathrm{f}$. dissectum and $A$. malesianum were lower than those of $A$. flabellulatum $(P<0.05)$.

\section{Plant element concentrations}

For the calcifuge A. flabellulatum, $\mathrm{Ca}, \mathrm{Mg}, \mathrm{Fe}$ and $\mathrm{Al}$ concentrations in leaves and roots were higher but $\mathrm{K}$ concentrations in leaves and roots were lower when grown on the calcareous soil than on the acidic soil $(P<$ 0.05 , Fig. 3). When grown on the mixed soil, root $\mathrm{Ca}$, $\mathrm{Mg}, \mathrm{Fe}$ and $\mathrm{Al}$ concentrations of $\mathrm{A}$. flabellulatum were higher and leaf $\mathrm{K}$ was lower than those on the acidic soil $(P<0.05)$.

In the calcicole $A$. capillus-veneris f. dissectum, root $\mathrm{Ca}, \mathrm{Mg}$, Fe and $\mathrm{Al}$ concentrations on acidic and mixed
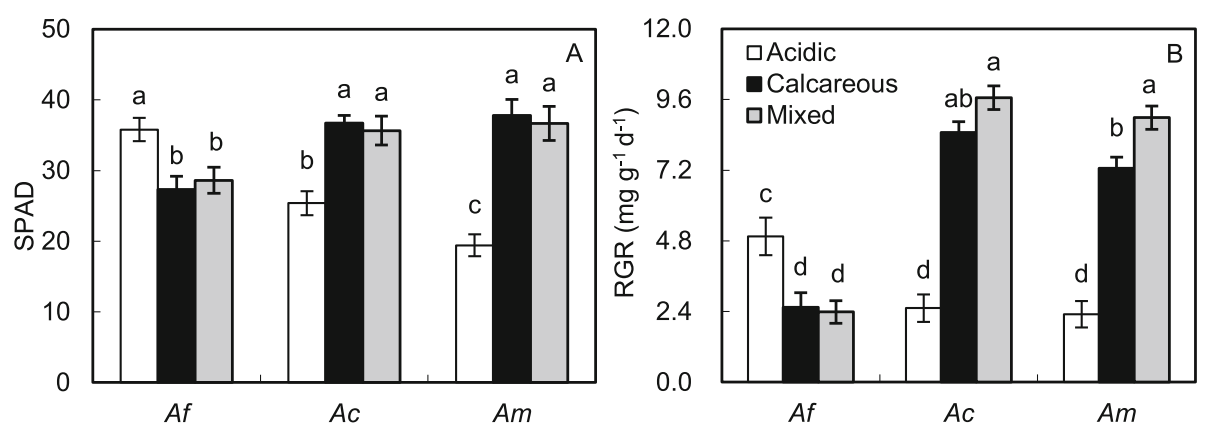

Fig. 2 SPAD values (a) and relative growth rate (RGR, b) of the calcifuge Adiantum flabellulatum ( $A f)$ and the calcicole $A$. capillus-veneris $\mathrm{f}$. dissectum $(A c)$ and $A$. malesianum (Am) grown on acidic, calcareous and mixed soils. Bar are means \pm SE of 7 replicates from two-way ANOVA (a) or two-way ANCOVA (b). Different letters indicate significant differences across all species $(P<0.05)$ 

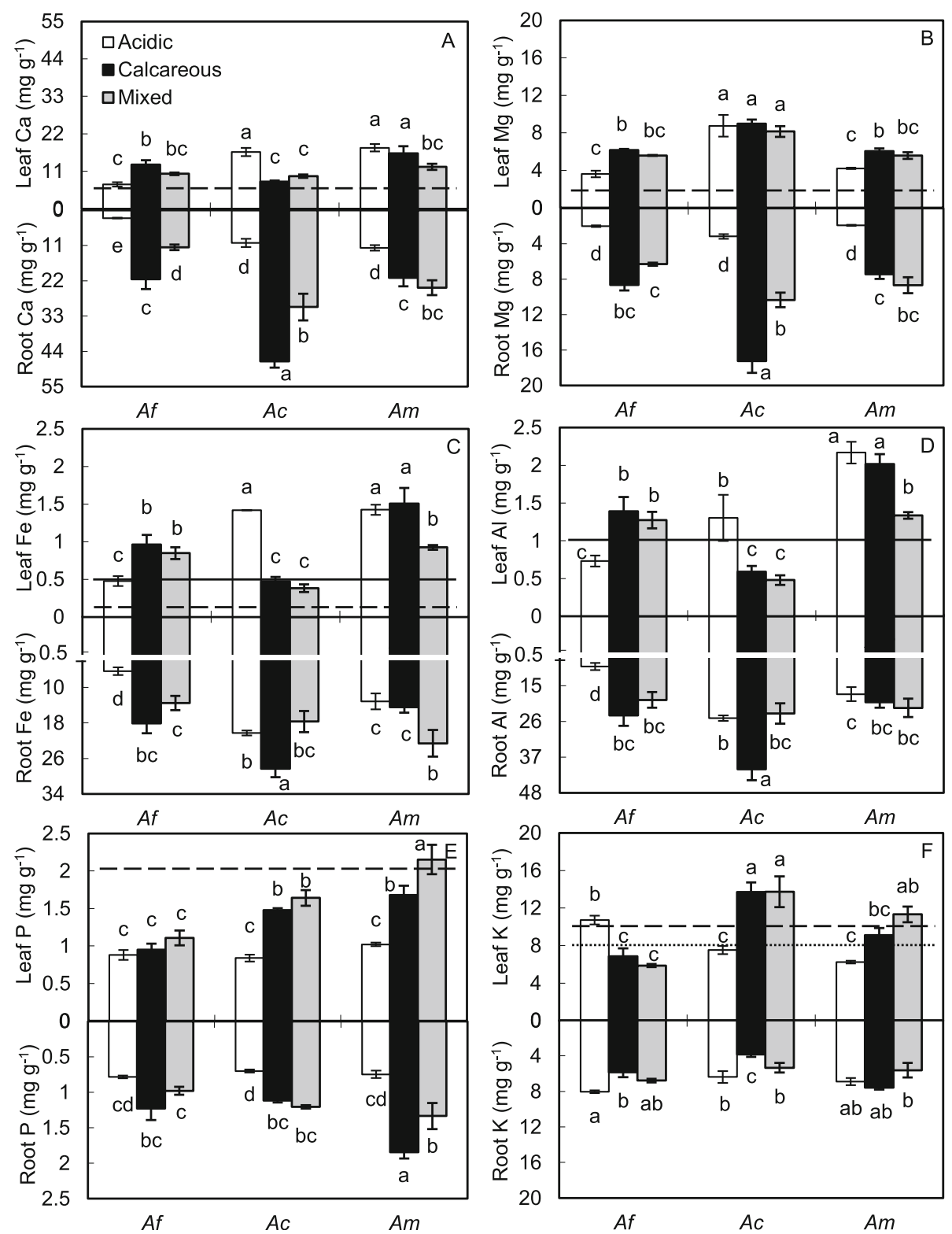

Fig. 3 Element concentrations in leaves and roots of the calcifuge Adiantum flabellulatum (Af) and the calcicole A. capillus-veneris f. dissectum (Ac) and A. malesianum (Am) grown on acidic, calcareous and mixed soils. Bar are means \pm SE of 7 replicates from two-way ANOVA. Different letters indicate significant differences within the same tissue and element $(P<0.05)$. The dashed lines represent the average leaf element concentrations sufficient for adequate growth [16]. The solid lines represent the critical Fe toxicity concentration [17] or the threshold to distinguish Alaccumulators $[18,19]$. The dotted line indicates the critical K deficiency concentration [20]

soils were lower and root $\mathrm{K}$ concentrations were higher than those on calcareous soil $(P<0.05$, Fig. 3). Leaf Ca, $\mathrm{Fe}$ and $\mathrm{Al}$ concentrations, however, were higher and leaf $\mathrm{P}$ and $\mathrm{K}$ were lower when grown on the acidic soil than on the calcareous soil $(P<0.05)$. When grown on the mixed soil, all leaf element concentrations were similar to those on the calcareous soil $(P>0.05)$.

Root $\mathrm{Ca}, \mathrm{Mg}$ and $\mathrm{P}$, and leaf $\mathrm{Mg}$ and $\mathrm{P}$ concentrations of $A$. malesianum were lower when grown on the acidic soil than on the calcareous soil $(P<0.05$, Fig. 3$)$. When grown on the mixed soil, root Fe and leaf $\mathrm{P}$ concentrations of $A$. malesianum, relative to those grown on the calcareous soil, were higher, but leaf $\mathrm{Ca}, \mathrm{Fe}, \mathrm{Al}$ and root $\mathrm{P}$ concentrations were lower $(P<0.05)$.

When grown on the acidic soil, A. flabellulatum had higher leaf $\mathrm{K}$ concentration, but lower leaf and root $\mathrm{Ca}$, $\mathrm{Fe}, \mathrm{Al}$ concentrations than the other two species $(P<$ 0.05 , Fig. 3). When grown on the calcareous and mixed soils, however, leaf $\mathrm{K}$ and $\mathrm{P}$ of $A$. flabellulatum were lowest. Relative to A. malesianum, A. capillus-veneris $\mathrm{f}$. 
dissectum exhibited higher leaf $\mathrm{Mg}$ but lower leaf $\mathrm{Al}$ concentration when grown on the same soil $(P<0.05)$, and lower leaf $\mathrm{Ca}$ and $\mathrm{Fe}$ but higher root $\mathrm{Ca}, \mathrm{Mg}, \mathrm{Fe}$ and $\mathrm{Al}$ when grown on the calcareous soil $(P<0.05)$.

\section{Correlations between leaf element and plant growth}

Final total biomass and RGR of the calcifuge A. flabellulatum correlated positively with leaf $\mathrm{K}$ and negatively with leaf $\mathrm{Mg}$, and RGR correlated negatively with leaf $\mathrm{Ca}$ $(P<0.05$, Table 2). For the calcicole A. capillus-veneris $\mathrm{f}$. dissectum, SPAD and RGR correlated negatively with leaf $\mathrm{Ca}, \mathrm{Fe}$ and $\mathrm{Al}$, but positively with leaf $\mathrm{P}$ and $\mathrm{K}(P<$ 0.05). For the calcicole $A$. malesianum, positive correlation coefficients were found for final total biomass and RGR with leaf $\mathrm{P}$ and $\mathrm{K}$, and final total biomass and SPAD with leaf $\mathrm{Mg}(P<0.05)$.

\section{Discussion}

Compared with acidic soils, calcareous soils are rich in $\mathrm{Ca}$ and $\mathrm{Mg}$ and have a neutral or higher $\mathrm{pH}[1,3]$. Some calcifuge plants adapted to severely $\mathrm{Ca}$-impoverished soils do not strongly down-regulate their Ca uptake capacity, and, consequently, are highly sensitive to calcareous soils [9]. They are excluded from calcareous soils also by their lacking ability to fulfill their requirements for other essential elements $[6,8]$, and this limitation may be further exacerbated by the reduced element availability at alkaline $\mathrm{pH}$ [21]. In contrast, calcicole plants can tolerate excess $\mathrm{Ca}$ and take up nutrients when grown on calcareous soils [6]. In the present study, the $\mathrm{pH}, \mathrm{Ca}, \mathrm{Mg}$ and $\mathrm{P}$ concentrations of the calcareous soil were higher but $\mathrm{K}$ concentration was lower than those of the acidic soil (Table 1). After $120 \mathrm{~d}$ of growth, all three Adiantum species on the calcareous soil exhibited higher root $\mathrm{Ca}$ and $\mathrm{Mg}$ concentrations than those on the acidic soil (Fig. 3), but their leaf $\mathrm{Ca}, \mathrm{Mg}, \mathrm{P}$ and $\mathrm{K}$, and RGR responded differently to soil types. When cultivated on the calcareous soil, leaf $\mathrm{Ca}$ and $\mathrm{Mg}$ concentrations of the calcifuge A. flabellulatum increased and leaf K, SPAD and RGR decreased (Figs. 2 and 3). The $\mathrm{Ca}$ and $\mathrm{Mg}$ requirements considered adequate for crop growth are $5.0 \mathrm{mg} \mathrm{Ca} \mathrm{g}^{-1}$ and $2.0 \mathrm{mg} \mathrm{Mg} \mathrm{g}^{-1}$ in leaves, respectively [16]. Leaf $\mathrm{K}$ concentration of $8.0 \mathrm{mg} \mathrm{g}^{-1}$ was suggested by De Wit et al. [20] based on Dutch agricultural grasslands as a tentative indicator of $\mathrm{K}$ deficiency. Leaf $\mathrm{Ca}, \mathrm{Mg}$ and $\mathrm{K}$ of A. flabellulatum were correlated with RGR (Table 2), but the former two elements on the calcareous soil were much more than the critical adequate concentrations (Fig. 3a, b) and leaf $\mathrm{K}$ was less than the critical deficiency value (Fig. 3f). In general, leaf $\mathrm{Mg}$ concentration beyond the growthlimiting level is unlikely to be detrimental because it can be stored mainly in the vacuoles, as a buffer for $\mathrm{Mg}^{2+}$ homeostasis in the metabolic pool and for charge compensation and osmoregulation in the vacuole [17]. In contrast, the strict compartmentation of $\mathrm{Ca}^{2+}$ at cellular level and maintenance of low $\mathrm{Ca}^{2+}$ concentrations in the cytosol are less effective in calcifuges than in calcicoles [17]. Therefore, $\mathrm{K}$ deficiency and excess Ca may exclude the calcifuge $A$. flabellulatum from calcareous soils. Conversely, leaf $\mathrm{Ca}$ concentration of the calcicole species on the calcareous soil did not change for $A$. malesianum and decreased for A. capillus-veneris f. dissectum, and leaf $\mathrm{P}$ and $\mathrm{K}$ concentrations, SPAD and RGR increased when compared with those grown on the acidic soil (Figs. 2 and 3), suggesting they can thrive on the calcareous soil by increasing leaf $\mathrm{P}$ and $\mathrm{K}$ uptake and retaining $\mathrm{Ca}$ in roots.

Table 2 Pearson correlation coefficients between leaf element concentrations and final total biomass, SPAD values and relative growth rate (RGR) for three Adiantum species

\begin{tabular}{|c|c|c|c|c|c|c|}
\hline & \multicolumn{6}{|c|}{ Leaf element concentration $\left(\mathrm{mg} \mathrm{g}^{-1}\right)$} \\
\hline & $\mathrm{Ca}$ & $\mathrm{Mg}$ & $\mathrm{Fe}$ & $\mathrm{Al}$ & $P$ & K \\
\hline \multicolumn{7}{|l|}{ A. flabellulatum } \\
\hline Final total biomass (g) & -0.43 & $-0.48^{*}$ & -0.34 & -0.35 & -0.37 & $0.53^{*}$ \\
\hline SPAD & -0.16 & -0.24 & -0.32 & -0.36 & -0.27 & 0.40 \\
\hline $\operatorname{RGR}\left(\mathrm{mg} \mathrm{g}^{-1} \mathrm{~d}^{-1}\right)$ & $-0.48^{*}$ & $-0.55^{*}$ & -0.38 & -0.40 & -0.40 & $0.67^{* *}$ \\
\hline \multicolumn{7}{|c|}{ A. capillus-veneris f. dissectum } \\
\hline Final total biomass (g) & -0.42 & 0.07 & -0.27 & -0.29 & 0.16 & 0.09 \\
\hline SPAD & $-0.67^{* *}$ & -0.12 & $-0.67^{* *}$ & $-0.51^{*}$ & $0.66^{* *}$ & $0.66^{* *}$ \\
\hline $\operatorname{RGR}\left(\mathrm{mg} \mathrm{g}^{-1} \mathrm{~d}^{-1}\right)$ & $-0.67^{* *}$ & 0.10 & $-0.67^{* *}$ & $-0.52^{*}$ & $0.66^{* *}$ & $0.49^{*}$ \\
\hline \multicolumn{7}{|l|}{ A. malesianum } \\
\hline Final total biomass (g) & -0.43 & $0.52^{*}$ & -0.28 & -0.36 & $0.50^{*}$ & $0.53^{*}$ \\
\hline SPAD & -0.03 & $0.67^{* *}$ & 0.12 & -0.32 & 0.33 & 0.32 \\
\hline $\operatorname{RGR}\left(\mathrm{mg} \mathrm{g}^{-1} \mathrm{~d}^{-1}\right)$ & -0.41 & 0.43 & -0.32 & -0.35 & $0.71^{* *}$ & $0.63^{* *}$ \\
\hline
\end{tabular}

\footnotetext{
${ }^{* *}$ indicate coefficient significant at $P<0.05$ and 0.01 , respectively $(n=21)$
} 
In the karst regions of southern China, limestone soils (calcareous) and red soils (acidic) are interlaced [1, 3]. Hence, they may "pollute" each other when extreme precipitation events occur [5]. In this study, we mixed the calcareous soil and the acidic soil at 1:1 and found the mixed soil had higher $\mathrm{pH}, \mathrm{Ca}, \mathrm{Mg}$ and $\mathrm{P}$ concentrations and lower $\mathrm{K}$ concentration than the acidic soil (Table 1). When grown on the mixed soil, the calcifuge A. flabellulatum, relative to its preferred acidic soil, had higher root $\mathrm{Ca}$ and $\mathrm{Mg}$ concentrations and lower leaf K, SPAD and RGR (Figs. 2 and 3). Such results showed A. flabellulatum will grow worse if the acidic soil is "polluted" by calcareous soils. For the calcicole A. capillus-veneris f. dissectum, leaf element concentrations and RGR were similar between the mixed soil and the calcareous soil (Figs. 2 and 3), indicating its growth will remain almost unaffected when the calcareous soil is "polluted" by acidic soils. On the contrary, the calcicole A. malesianum grew better, as evidenced by higher RGR (Fig. 2b), when cultivated on the mixed soil than on the calcareous soil. Chrysargyris et al. [22] suggested well balanced nutrients can improve plant growth by affecting the availability, transport, and partitioning of the nutrients. We also thought the element levels of the mixed soil, although lower $\mathrm{P}$ concentration relative to the calcareous soil (Table 1), might be more balanced for A. malesianum, and hence its RGR were highest and the leaf $P$ was close to the sufficient concentration of $2.0 \mathrm{mg} \mathrm{g}^{-1}$ considered adequate for crop growth [16] (Fig. 3e). In addition, the higher leaf $\mathrm{P}$ for $A$. malesianum on the mixed soil, compared to the calcareous soil, could be also related to lower soil $\mathrm{Ca}$ and $\mathrm{Mg}$ concentrations. In soils, $\mathrm{Ca}$ and $\mathrm{Mg}$ can reduce $\mathrm{P}$ bioavailability by forming poorly soluble Ca-P and Mg-P [23-25].

Iron deficiency is also suggested to exclude some calcifuge plants from calcareous soils [6] and $\mathrm{Al}$ toxicity excludes calcicole plants from acidic sites [12]. In this study, $\mathrm{Fe}$ and $\mathrm{Al}$ were similar among acidic, calcareous and mixed soils (Table 1). The calcifuge A. flabellulatum, however, had higher leaf and root Fe concentrations and its leaf $\mathrm{Fe}$ exceeded the critical toxicity concentration of $0.5 \mathrm{mg} \mathrm{g}^{-1}$ [17] when grown on the calcareous and mixed soils than on the acidic soil (Fig. 3c). Therefore, its chlorotic and necrotic symptoms on leaves when forced to grow on calcareous or mixed soils might not be due to a lack of Fe. However, we only measured total leaf Fe and not biologically available Fe. Zohlen and Tyler [8] argued Fe immobilization in physiologically less active forms in leaf tissue may also exclude calcifuge plants with adequate total leaf Fe from calcareous soils. In general, a value of $1.0 \mathrm{mg} \mathrm{Al} \mathrm{g}^{-1}$ leaf dry mass is a threshold to distinguish $\mathrm{Al}$ accumulators and non- $\mathrm{Al}$ accumulators $[18,19]$. The calcifuge A. flabellulatum and the calcicole A. capillus-veneris $\mathrm{f}$. dissectum might be $\mathrm{Al}$ excluder species because their leaf $\mathrm{Al}$ concentrations were lower than the threshold when grown on their respective preferred soils (Fig. 3d), whereas the calcicole $A$. malesianum might be an $\mathrm{Al}$ includer species since its leaf $\mathrm{Al}$ concentrations were more than the threshold on all three soil types (Fig. 3c, d). When forced to grow on the acidic soil, $A$. capillus-veneris $\mathrm{f}$. dissectum had lower RGR (Fig. 2b) and its leaf $\mathrm{Al}$ concentration exceeded the threshold (Fig .3d). The results, however, might not indicate the calcicole species experienced Al toxicity. First, the evident symptoms of Al toxicity, which the root apices and laterals became thick, stubby and brown in appearance [26], did not occur. Second, all the Ca/Al molar ratios in roots, the superior indicators than the leaf $\mathrm{Al}$ concentration for evaluating $\mathrm{Al}$ toxicity and acidity stress to plants [26, 27], were above the critical 0.2 for the calcicole species on three soil types.

Wang et al. [2] found that A. capillus-veneris f. dissectum was a calcicole species with low $\mathrm{Ca}$ concentration. In our study, leaf Ca concentration of A. capillus-veneris f. dissectum was similar to the calcifuge A. flabellulatum but lower than the calcicole $A$. malesianum when grown on their respective preferred soils (Fig. 3a). The results further indicated that the calcicole A. capillus-veneris $\mathrm{f}$. dissectum is a low leaf Ca species. Nevertheless, its root $\mathrm{Ca}$ concentration was highest among the three species (Fig. 3a), implying a Ca exclusion strategy enabling it to avoid excess leaf $\mathrm{Ca}$ by retaining $\mathrm{Ca}$ in roots. In contrast, the calcicole $A$. malesianum had an almost 2-fold greater leaf $\mathrm{Ca}$ concentration than A. capillus-veneris $\mathrm{f}$. dissectum under calcareous conditions (Fig. 3a), suggesting it take up the extra $\mathrm{Ca}$ and can tolerate the higher leaf $\mathrm{Ca}$. The tolerance is most likely achieved through biomineralization of excess $\mathrm{Ca}$, forming Ca-based minerals (presumably Caoxalate), thus avoiding any interference from $\mathrm{Ca}^{2+}$ on cell functioning and the availability/allocation of other nutrients [28]. This idea of interspecific variation in the ability of Adiantum species to form Ca-oxalate crystals is supported by Anthoons [29].

\section{Conclusion}

The calcifuge A. flabellulatum performed worse on the calcareous soil. Such a response might be attributed to the increased leaf $\mathrm{Ca}$ concentration and decreased leaf $\mathrm{K}$ concentration. In contrast, the calcicole $A$. capillusveneris $\mathrm{f}$. dissectum and $A$. malesianum could effectively take up $\mathrm{P}$ and $\mathrm{K}$ to leaves and hence thrive on the calcareous soils. Relative to A. malesianum, A. capillusveneris $\mathrm{f}$. dissectum is a low leaf $\mathrm{Ca}$ calcicole species. If their preferred calcareous soils are "polluted" by acidic soils, A. capillus-veneris $\mathrm{f}$. dissectum can remain almost unaffected while $A$. malesianum will grow better. Conversely, A. flabellulatum will grow worse if its optimum acidic soil is "polluted" by calcareous soils. 


\section{Methods}

\section{Plant materials and growth conditions}

A. capillus-veneris f. dissectum (M. Martens \& Galeotti) Ching, A. malesianum J. Ghatak and A. flabellulatum L. are perennial evergreen ferns of the family Pteridaceae. In the karst region of Guangxi, South China, A. capillusveneris $\mathrm{f}$. dissectum and $A$. malesianum occur on limestone soils (calcareous), but $A$. flabellulatum is restricted to red and yellow soils (acidic). A. capillus-veneris f. dissectum, height $15-40 \mathrm{~cm}$, features slender and creeping rhizomes, and ovate-triangular and 1- or 2-pinnate laminas. A. malesianum, $10-40 \mathrm{~cm}$ tall, possesses short and erect rhizomes and whiplike 1-pinnate laminas, and can form new plantlet by rachis rooting at apex. A. flabellulatum, named after its flabellate and 2- or 3dichotomously branched laminas, is $20-45 \mathrm{~cm}$ tall and possesses short and erect rhizomes.

These three Adiantum species can be propagated by rhizome separation. In April 2017, mother plants of $A$. capillus-veneris f. dissectum and $A$. malesianum were obtained from Yangshuo County, Guangxi $\left(24^{\circ} 43^{\prime} \mathrm{N}\right.$, $\left.110^{\circ} 30^{\prime} \mathrm{E}\right)$, and A. flabellulatum were collected from Guilin Botanical Garden, Guangxi, South China (250.' $\left.\mathrm{N}, 110^{\circ} 18^{\prime} \mathrm{E}\right)$. They were identified by Professor Yan Liu from Guangxi Institute of Botany and Voucher specimens were deposited at the Guangxi herbarium (http:// www.gxib.cn/spIBK). For each species, 7 mother plants with similar size were selected and each plant was separated into three cloned individuals. The three clones were randomly assigned to three pots (height $16 \mathrm{~cm}$ and diameter $18 \mathrm{~cm}$ ) containing different soil types (calcareous, acidic and mixed soils, $2 \mathrm{~kg}$ ). Thus, there were 21 pots (7 individuals $\times 3$ soil types) for each species. The pots stayed on benches, randomly distributed inside a shaded plastic greenhouse, according to Liao et al. [15]. During the period (April 28 to August 26, 2017), the average day/night temperature and humidity were 30.4 / $23.3^{\circ} \mathrm{C}$ and $75.1 \%$, respectively.

The calcareous soil was collected from root zone (the top $20 \mathrm{~cm}$ of soil within a $20 \mathrm{~cm}$ radius) of A. capillusveneris f. dissectum from Yangshuo County, Guangxi, and the acidic soil was obtained from A. flabellulatum root zone in Guilin Botanical Garden, Guangxi, South China. These soils were dried in the shade under room temperature and sieved $(0.5 \mathrm{~cm})$ to remove pebbles, leaves and unwanted material. The mixed soil was a mixture of the calcareous and the acidic soils $(1: 1, \mathrm{v} / \mathrm{v})$. For each pot, soil was watered to $60 \%$ of field capacity every 2 days by commonly-used weight method.

\section{Measurements}

Before being potted, soil $\mathrm{pH}$ was determined in $\mathrm{CaCl}_{2}$, and total $\mathrm{Ca}, \mathrm{Mg}, \mathrm{Fe}, \mathrm{Al}, \mathrm{P}, \mathrm{K}$ concentrations were determined by inductively coupled plasma-optical emission spectrometry (ICP-OES, Agilent 725, Agilent Technologies, USA) after microwave digestion with $1: 3 \mathrm{HNO}_{3}$ : $\mathrm{HCl}$ [30]. The initial fresh weights of all plant individuals were recorded, and their dry weights (initial total biomass, $\mathrm{DW}_{1}$ ) were estimated based on the dry weight/ fresh weight ratios of subsamples analyzed in the laboratory.

After 4 months of growth, chlorophyll levels of newly formed and mature leaves were determined using a SPAD-502 chlorophyll meter (Minolta, Osaka, Japan) and then all the plants were harvested. For each individual, final total biomass $\left(\mathrm{DW}_{2}\right)$ was obtained after being washed with tap water carefully and then oven-dried at $80{ }^{\circ} \mathrm{C}$ for at least $24 \mathrm{~h}$. From $\mathrm{DW}_{1}$ and $\mathrm{DW}_{2}$, the relative growth rate per day (RGR, $\mathrm{mg} \mathrm{g}^{-1} \mathrm{~d}^{-1}$ ) was estimated as $\left(\ln \mathrm{DW}_{2}-\ln \mathrm{DW}_{1}\right) / 120 \times 1000$. After measuring the biomass, leaf and root samples were ground and homogenized. The samples were digested with 5:1 $\mathrm{HNO}_{3}$ : $\mathrm{HClO}_{4}[13]$ and the concentrations of $\mathrm{Ca}, \mathrm{Mg}, \mathrm{Fe}, \mathrm{Al}, \mathrm{P}$ and $\mathrm{K}$ were determined by inductively coupled plasmamass spectrometry (ICP-MS, iCAP-Qc, ThermoFisher Scientific, USA).

\section{Statistical analysis}

Differences of soil properties were compared using oneway analysis of variance (ANOVA) followed by least significant difference (LSD) $(P<0.05)$. Differences of SPAD values, element concentrations ( $\mathrm{Ca}, \mathrm{Mg}, \mathrm{Fe}, \mathrm{Al}, \mathrm{P}$ and $\mathrm{K}$ ) among species and soil types were tested by two-way ANOVA. Since biomass production and RGR are initial size dependent [31], their differences among species and soil types were tested by two-way analysis of covariance (ANCOVA), with $\mathrm{DW}_{1}$ as a covariate. For each species, linear correlations between the measured leaf element concentrations and final total biomass, SPAD values and RGR were tested by Pearson correlation coefficient. All analyses were conducted using SPSS 20.0 for Windows (SPSS Inc., Chicago, USA).

\section{Abbreviations}

Af: Adiantum flabellulatum; Ac: Adiantum capillus-veneris f. dissectum Am: Adiantum malesianum; RGR: Relative growth rate; $\mathrm{DW}_{1}$ : Initial total biomass; $\mathrm{DW}_{2}$ : Final total biomass

\section{Acknowledgements \\ We thank Ms. LingLi Zou for sample information of plant materials, Professor Yan Liu for species identification. We also thank Riya Mondal, the Submission Editor at Springer Nature, recommended the Journal to our manuscript. \\ Authors' contributions \\ JXL performed most of the experiments and wrote the manuscript. DYL helped to measure and analyze the data. QWJ, LM and DZ collected plants and soils from field. GZP helped to design the experiments. All the authors have read and approved the final manuscript.}

Funding

This research was supported by the National Natural Science Foundation of China (31560089, 41867054), the National Key R\&D Program of China (2019YFC0507503), the Natural Science Foundation of Guangxi, China 
(2018GXNSFAA281108), the Key R\&D Program of Guangxi, China (Guike AB16380250), and the Science and Technology Major Project of Guilin, China (20180101-2). None of the funding bodies had any role in the design of the study and collection, analysis, and interpretation of data and in preparing the manuscript.

\section{Availability of data and materials}

The datasets used and/or analysed during the current study are available from the corresponding author on reasonable request.

\section{Ethics approval and consent to participate}

The mother plants and root zone soils of three Adiantum species in the present study were obtained from public land with the permissions of Guilin government. The pot experiments on such plants, including their field collection, were performed at Guilin Botanical Garden, and they complied with the national guidelines of China and the Convention on the Trade in Endangered Species of Wild Fauna and Flora.

\section{Consent for publication}

Not applicable.

\section{Competing interests}

The authors declare that they have no competing interests.

Received: 30 July 2019 Accepted: 5 July 2020

Published online: 10 July 2020

\section{References}

1. Cao JH, Yuan DX, Pan GX. Some soil features in karst ecosystem. Adv Earth Science. 2003;18:37-44 (in Chinese with English abstract).

2. Wang CY, Wang SJ, Rong L, Luo XQ. Analyzing about characteristics of calcium content and mechanisms of high calcium adaptation of common Pteridophyte in Maolan karst area of China. Chin J Plant Ecol. 2011;35:10619 (in Chinese with English abstract)

3. Huang SX, Li RT, Luo WH, Zhou TJ, Tang WX, Wang Y. Variation in characteristics of rare and threatened plants after ex-situ conservation. Biodivers Sci. 2001;9:359-65 (in Chinese with English abstract).

4. Huang ZH, Lu QF, Chen YZ. Comparative study on reproductive success of Corydalis sheareri (Papaveraceae) between alkaline limestone soil and red soil habitats in a karst area. Biodivers Sci. 2017;25:972-80 (in Chinese with English abstract).

5. Liu MX, Xu XL, Sun A, Wang KL, Liu W, Zhang XY. Is southwestern China experiencing more frequent precipitation extremes? Environ Res Lett. 2014; 9:064002.

6. Venturas M, Fernandez V, Nadal P, Guzmán P, Lucena JJ, Gil L. Root iron uptake efficiency of Ulmus laevis and U minor and their distribution in soils of the Iberian Peninsula. Front Plant Sci. 2014;5:104.

7. Lyu Y, Tang H, Li H, Zhang F, Rengel Z, Whalley WR, Shen J. Major crop species show differential balance between root morphological and physiological responses to variable phosphorus supply. Front Plant Sci. 2016;7:1939

8. Zohlen A, Tyler G. Immobilization of tissue iron on calcareous soil: differences between calcicole and calcifuge plants. Oikos. 2000;89:95-106.

9. Zohlen A, Tyler G. Soluble inorganic tissue phosphorus and calcicolecalcifuge behaviour of plants. Ann Bot. 2004;94:427-32.

10. Hayes PE, Guilherme Pereira C, Clode PL, Lambers H. Calcium-enhanced phosphorus-toxicity in calcifuge and soil-indifferent Proteaceae along the Jurien Bay chronosequence. New Phytol. 2018;221:764-77.

11. Paul A, Hauck M, Leuschner C. Iron and phosphate uptake explains the calcifuge-calcicole behavior of the terricolous lichens Cladonia furcata subsp. furcata and C. rangiformis. Plant Soil. 2009;319:49-56.

12. Kochian LV, Piñeros MA, Liu J, Magalhaes JV. Plant adaptation to acid soils: the molecular basis for crop aluminum resistance. Annu Rev Plant Biol. 2015:66:571-98.

13. de Souza MC, Habermann G. Do Amaral CL, Rosa AL, Pinheiro MHO, Da Costa FB. Vochysia tucanorum Mart.: an aluminum-accumulating species evidencing calcifuge behavior. Plant Soil. 2017;419:377-89.

14. Lin YX. New taxa of Adiantum in China. Acta Phytotax Sin. 1980;18:101-5 (in Chinese).
15. Liao JX, Zhang $H$, Mo L, Huang YQ, Sun YJ, Li YQ. Differences in growth and biomass allocation of Adiantum flabellulatum and A. capillus-veneris as a result of light and water availability. Bot Lett. 2017;164:393-400.

16. Epstein E, Bloom AJ. Mineral nutrition of plants: principles and perspectives. 2nd ed. Sunderland: Sinauer Associates; 2005.

17. Marschner P. Marschner's mineral nutrition of higher plants. 3rd ed. San Diego: Elsevier/Academic Press; 2012.

18. Jansen S, Watanabe T, Smets E. Aluminium accumulation in leaves of 127 species in Melastomataceae, with comments on the order Myrtales. Ann Bot. 2002;90:53-64.

19. Metali F, Salim KA, Burslem DFRP. Evidence of foliar aluminium accumulation in local, regional and global datasets of wild plants. New Phytol. 2012;193:637-49.

20. De Wit CT, Dijkshoorn W, Noggle JG. Ionic balance and growth of plants: Wageningen, Verslagen van Landbouwkundige Onderzoeken; 1963.

21. Cross AT, Stevens JC, Sadler R, Moreira-Grez B, Ivanov D, Zhong H, Dixon $\mathrm{KW}$, Lambers $\mathrm{H}$. Compromised root development constrains the establishment potential of native plants in unamended alkaline post-mining substrates. Plant Soil. 2018. https://doi.org/10.1007/s11104-018-3876-2.

22. Chrysargyris A, Michailidi E, Tzortzakis N. Physiological and biochemical responses of Lavandula angustifolia to salinity under mineral foliar application. Front Plant Sci. 2018:9:489.

23. Piao HC, Liu CQ, Zhu SF, Zhu JM. Variations of $C_{4}$ and $C_{3}$ plants N:P ratios influenced by nutrient stoichiometry in limestone and sandstone areas of Guizhou. Quaternary Sci. 2005;5:552-60 (in Chinese with English abstract).

24. Luo XQ, Wang SJ, Wang CY, Liao XR. Adaptability and regulation mechanisms of plants on phosphorus stress in calcareous soil. Chin Agric Sci Bull. 2011;27:223-8 (in Chinese with English abstract).

25. Pang JY, Yang JY, Lambers $H$, Tibbett $M$, Siddique KHM, Ryan $M H$. Physiological and morphological adaptations of herbaceous perennial legumes allow differential access to sources of varyingly soluble phosphate. Physiol Plant. 2015;154:511-25.

26. Vanguelova El, Hirano Y, Eldhuset TD, Sas-Paszt L, Bakker MR, Püttsepp Ü, Brunner I, Lõhmus K, Godbold D. Tree fine root Ca/Al molar ratio - Indicator of $\mathrm{Al}$ and acidity stress. Plant Biosyst. 2007:141:460-80.

27. Cronan CS, Grigal DF. Use of calcium/aluminum ratios as indicators of stress in forest ecosystems. J Environ Qual. 1995:24:209-26.

28. Hayes PE, Clode PL, Guilherme Pereira C, Lambers H. Calcium modulates leaf cell-specific phosphorus allocation in Proteaceae from South-Western Australia. J Exp Bot. 2019;70:3995-4009.

29. Anthoons B. Distribution of calcium oxalate crystals in ferns and lycophytes: Ghent University; 2017

30. Ministry of Environmental Protection. National Environmental Protection Standard of the People's republic of China (HJ 832-2017): soil and sediment - digestion of total metal elements - microwave assisted acid digestion method. Beijing: China Environmental Science Press; 2017. (in Chinese).

31. Valladares F, Wright SJ, Lasso E, Kitajima K, Pearcy RW. Plastic phenotypic response to light of 16 congeneric shrubs from a Panamanian rainforest. Ecology. 2000;81:1925-36.

\section{Publisher's Note}

Springer Nature remains neutral with regard to jurisdictional claims in published maps and institutional affiliations.

Ready to submit your research? Choose BMC and benefit from

- fast, convenient online submission

- thorough peer review by experienced researchers in your field

- rapid publication on acceptance

- support for research data, including large and complex data types

- gold Open Access which fosters wider collaboration and increased citations

- maximum visibility for your research: over $100 \mathrm{M}$ website views per year

At BMC, research is always in progress.

Learn more biomedcentral.com/submissions 